\title{
Ontogeny of prey selection by black surfperch Embiotoca jacksoni (Pisces: Embiotocidae): the roles of fish morphology, foraging behavior, and patch selection
}

\author{
Russell J. Schmitt and Sally J. Holbrook
}

Department of Biological Sciences and the Marine Science Institute, University of California, Santa Barbara, California 93106, USA

\begin{abstract}
Proximate mechanisms leading to similarities and differences in diets of juvenile and adult black surfperch Embiotoca jacksoni in populations at Santa Catalina Island (USA) were explored. These fish are microcarnivorous, harvesting invertebrate prey primarily from benthic turf and foliose algae. Ontogenetic differences in prey size ultimately reflect age-specific differences in size of fish. Young juveniles are apparently gape limited and use a visual picking mode of foraging. This strongly influences the array of algal substrates from which prey can be effectively harvested. Turf substrates are used extensively by older fish that employ winnowing behavior to separate prey from debris. The ability to winnow develops slowly during the first year of life and allows exploitation of turf, a preyrich, extensive resource base. The marked differences in body size and foraging behavior have only a relatively small influence on the gross taxonomic makeup of the diets of black surfperch.
\end{abstract}

\section{INTRODUCTION}

Many species of predators are characterized by ontogenetic dietary shifts. Marked changes often occur between juvenile and adult stages. Among small vertebrate species, ontogenetic shifts in diet have been described for snakes (e.g. Burghardt, 1978; Mushinsky et al., 1982), lizards (e.g. Schoener, 1968), and fishes (e.g. Carr and Adams, 1973; Coyer, 1979; Grossman, 1980; Lemly and Dimmick, 1982). A suite of potentially interacting factors has been posited to account for ontogenetic dietary patterns. These include agespecific morphological constraints, foraging behavior, habitat selection, and prey availability.

Age-specific dietary change is a well-documented phenomenon among microcarnivorous fishes (e.g. Keast, 1965, 1968, 1977a, b, 1978a, b; Flemer and Woolcott, 1966; Carr and Adams, 1973; Cadwallader, 1975; Heins and Clemmer, 1975; Kislalioglu and Gibson, 1976a, b; Ross, 1977; Helfman, 1978; Cadwallader and Eden, 1979; Coyer, 1979; George and Hadley, 1979; Macpherson, 1979; Coates, 1980; Grossman, 1980; Grossman et al., 1980; Leum and Choat, 1980; Lemly and Dimmick, 1982). However, the mechanisms that produce these patterns in field populations have rarely been investigated in detail, probably because of the difficulty of delineating constraints and relating them to diets of predators. Both the size of prey items and the taxa that comprise a diet can differ among age classes of a fish species. Body size of a predator (agerelated in fish) can determine the maximum or average size of prey that is consumed (Hespenheide, 1973). Since prey of different size tend to be of qualitatively different type (Hespenheide, 1971, 1975), ontogenetic changes in taxonomic composition of the diet may simply reflect differential abilities to harvest prey of various sizes. Diets of juvenile fish can differ taxonomically from those of adults for a variety of other, often complex reasons (e.g. Kislalioglu and Gibson, 1976a, b; Keast, 1978a; George and Hadley, 1979; Coates, 1980; Grossman, 1980; Grossman et al., 1980; Mittelbach, 1981).

We explored mechanisms producing dietary differences between juvenile and adult black surfperch Embiotoca jacksoni (Pisces: Embiotocidae). First, similarities and differences in the diets of 2 age classes of black surfperch (young of the year $[\mathrm{O}+]$ and older individuals $[\geqslant 1]$ ) were quantified. Second, we investi- 
gated the relative importance of fish size, foraging behavior, microhabitat selection, and characteristics of available prey in shaping diets. Each of these factors has been identified as a possible determinant of ontogenetic changes in diets of other species of fish.

\section{METHODS}

The fish species. Embiotoca jacksoni is a common inhabitant of shallow rocky subtidal areas off the west coast of North America, especially in southern California (Tarp, 1952; Isaacson and Isaacson, 1966; DeMartini, 1969; Ebeling et al., 1980a, b; Hixon, 1980a). Individuals can live up to about $6 \mathrm{yr}$ and reach standard lengths (SL) greater than $250 \mathrm{~mm}$. At our study sites the mean age of adults was approximately $2 \mathrm{yr}$, corresponding to a mean SL of about $160 \mathrm{~mm}$. At this length, females bear 5 to 10 large, fully developed young ( 50 to $60 \mathrm{~mm} \mathrm{SL}$ at birth) once each year (Baltz, in press; Holbrook and Schmitt, unpubl.). Young remain in the same general habitat as adults and they immediately assume a microcarnivorous habit (Holbrook and Schmitt, in press). Like adults, juveniles feed on invertebrates, primarily gammarid amphipods, located on algae and 'turf', a low lying matrix of plants and colonial animals that can cover rocky substrates (DeMartini, 1969; Ellison et al., 1979; Schmitt and Coyer, 1982; Laur and Ebeling, 1983). Feeding is diurnal (Ebeling and Bray, 1976; Laur and Ebeling, 1983), with adults and juveniles foraging in the same area and depth range. Black surfperch are capable of winnowing, a mode of foraging behavior in which edible prey in mouthfuls of debris-laden substrate are separated and swallowed. The remaining undesired material is ejected from the mouth in a cast (Schmitt and Coyer, 1982; Laur and Ebeling, 1983). Fish are residential on local reefs but, with the exception of a few large males that defend caves or shelters for breeding (Hixon, 1980b, 1981), they are not strictly territorial. Sexual maturity is usually reached in the second year of life (Baltz, in press; Holbrook and Schmitt, unpubl.).

Study sites. All field work was conducted on the lee side of Santa Catalina Island, California $\left(33^{\circ} 27^{\prime} \mathrm{N}_{\text {; }}\right.$ $118^{\circ} 20^{\prime} \mathrm{W}$ ). Observations and collections of juvenile and adult black surfperch were made at 3 sites near the Catalina Marine Science Center: Lionshead Cove, Big Fisherman Cove, and Isthmus Reef. Observations of foraging fish were made from May to Sep 1981 and from Mar to May 1982. To reduce possible seasonal variation, fish taken for dietary analyses, together with resource samples to estimate characteristics of available prey, were confined to the storm-free, warm-water months (May to Nov) of 1981. Coyer (1979) found that temporal variability in taxa, size, and densities of invertebrate species associated with kelp-bed algal substrates was extremely small during this portion of the year.

The substrates at each study site were similar with respect to algal composition. The substrate at Lionshead was composed predominantly of boulders and cobble on benchrock which sloped gradually from above the intertidal zone to sand at depths of 12 to $15 \mathrm{~m}$. A variety of species of foliose algae (all less than $\sim 50 \mathrm{~cm}$ in height) and encrusting coralline algae, as well as a low (less than $10 \mathrm{~cm}$ high) matrix of plants and colonial animals comprising the category 'turf' (Hixon, 1980a; Schmitt and Coyer, 1982; Holbrook and Schmitt, in press), covered the entire rocky surface. Small patches (1 to $\left.2 \mathrm{~m}^{2}\right)$ of turf alternated with areas covered by mixtures of foliose algal species. The Isthmus Reef site was a shallow reef ( 3 to $10 \mathrm{~m}$ depth) with boulders and cobble covered by turf and foliose algae. In Big Fisherman Cove, observations were made on a rocky bench in 3 to $5 \mathrm{~m}$ of water. The bench sloped gently from above the water line to sand at about $7 \mathrm{~m}$. Detailed descriptions of these study sites are reported elsewhere (Holbrook and Schmitt, in press). Methods used to estimate percent cover of algal species are given below.

Dietary studies. Fish used for dietary analysis were speared between 0900 and $1200 \mathrm{~h}$ at Lionshead and Isthmus Reef ( $\mathrm{N}=44$ adults; $\mathrm{N}=80$ juveniles). Since Embiotoca jacksoni began to forage with an empty gut at daylight and fed heavily during the morning (Ebeling and Bray, 1976), collecting fish during late morning ensured that the majority of guts would be full. Adult and juvenile (young of the year) fish were speared as they were encountered until approximately 10 individuals of each group were collected. Juveniles were taken monthly (except Oct) between May and Nov 1981 to estimate growth and establish whether marked changes in diet occurred during the initial $6 \mathrm{mo}$ of life. All of these juveniles were collected from a large population at Lionshead, except for a group of 10 taken at Isthmus Reef in May for comparative purposes. Adults were taken from Lionshead $(\mathrm{N}=27)$ and from Isthmus Reef $(N=17)$. Diets of fish collected from the 2 sites did not differ, so all fish were pooled in subsequent analyses. Schmitt and Coyer (1982) showed that there is little within-individual variability in diets of adult black surfperch.

Fish were processed immediately after spearing. The gut of each fish, consisting of a simple undifferentiated tube, was removed and placed in a $10 \%$ solution of buffered aqueous formaldehyde. Fish were weighed, measured (standard length), and sexed. Otoliths were removed for use in age determination.

The contents of the entire gut of each fish were examined under a dissecting microscope. All items in 
13 taxonomic groups (Table 1) were sorted, identified and counted. The lengths (or widths when appropriate) of a sample of up to 100 individuals per prey taxon in a gut were measured using an ocular micrometer. Length-weight relations developed by Coyer (1979) for Santa Catalina invertebrates enabled estimation of the biomass of each measured item in every fish gut. By this means, we were able to estimate the contributions of each taxon to the total biomass in the diet of individual fish. Items within a taxon were placed into a series of 9 prey weight classes to facilitate betweenfish comparisons of size distributions of prey. Selectivity by fish for items in the 9 weight classes was calculated for individuals using the preference index, $\underline{\alpha}$, of Manly (1974; Chesson, 1978, 1981, 1983). This particular measure has a number of advantages over other indices; perhaps the most important is that $\alpha$ does not vary with changes in the relative abundances of prey items unless the behavior of the predator changes (Chesson, 1983). Further, $\alpha$ is approximately multivariate normally distributed (Chesson 1981, 1983), allowing comparison of preferences of adults and juveniles using MANOVA.

The degree of similarity in diets of fish of different age was investigated using discriminant function analyses (BMDP7M). Taxonomic and prey size class compositions were considered separately.

Since gammarid amphipods comprised more than half of the diets of Embiotoca jacksoni at Santa Catalina and were important components of the invertebrate fauna associated with algal substrates (Schmitt and Coyer, 1983; Holbrook and Schmitt, in press), we investigated this prey taxon in detail. A sample of 300 randomly selected gammarid amphipod individuals was obtained from each group of fish and from each of 3 foraging substrate groups; the latter were determined by the preference patterns displayed by fish (see below). Individual amphipods were identified to the lowest possible taxonomic level: species, genus, or family. Further, gammarids were also classified into 1 of 2 groups based on lifestyle: tubicolous (where individuals construct tubes) or free-living (Barnard, 1969, 1975). The mode of life of a gammarid amphipod might influence its availability to a foraging fish, as well as its general desirability since tubes are presumably not nutritious (Laur and Ebeling, 1983). The frequency of each type of gammarid on the 3 substrate categories was estimated to compare availability with ingestion by the two age classes of black surfperch.

The relations between fish size and mean prey size or size of the largest prey item were explored with linear regression (SAS SYSREG). Juvenile and adult age classes were treated separately in these analyses.

Substrate selection and prey resource availability.
The patterns of patch use displayed by foraging black surfperch were established by observing fish in the field between 0800 and $1400 \mathrm{~h}$. Individual actively foraging fish were followed for up to $6 \mathrm{~min}$. The time elapsed between successive bites was measured, as was the time (and occurrence) of winnowing following a bite. The type of foraging substrate was also recorded for each bite. The standard length of each fish was estimated; samples of subsequently speared fish verified that visual estimates were within $10 \%$ of actual length. Forty-eight adult and 36 juvenile fish were observed at Lionshead, which collectively took 960 and 800 bites. The relative abundance of available foraging substrates was estimated using line transects. A total of eight $50 \mathrm{~m}$ long line transects yielded 400 point samples (1 randomly chosen point per $\mathrm{m}$ ) of available substrate types. An additional 16 adults and 17 young born in 1981 were observed in Big Fisherman Cove in March 1982.

For analyses of foraging substrate selectivity, algal substrates were placed into categories (Table 4) based on their general morphology and growth form: (1) planar substrates that were relatively flat or encrusting; (2) shrub-like species that included low (up to $25 \mathrm{~cm}$ ) foliose forms with a moderate degree of 3-dimensionality; and (3) bush-like algae that were the most 3-dimensional and the tallest (up to $50 \mathrm{~cm}$ ).

Samples of algae were obtained during Jun-Jul 1981 at Lionshead and Isthmus Reef so that availability of prey to foraging fish could be assessed. Individual plants of a variety of species were collected by carefully placing a plastic bag over the entire plant and prying its holdfast off the rock; the bag was then quickly sealed. This method resulted in little loss of invertebrates from the algae. In the laboratory, algal specimens were pulled apart and invertebrates were washed off by repeated and vigorous agitation. Prey were then preserved in a $10 \%$ solution of buffered aqueous formaldehyde. Individual plants were weighed (damp). A total of 60 foraging substrate samples representing a wide range of growth forms and preference by black surfperch was obtained (Table 6). Prey collected from each was identified, counted, and measured in the same fashion as were the gut contents of fish.

To facilitate comparison of gut contents with prey availability, we placed various foraging substrates into 3 groups based on their relative preference by black surfperch: (1) substrates favored principally by adults (i.e. turf and erect coralline algae); (2) those favored mainly by juveniles (i.e. Zonaria farlowii, Dictyopteris undulata, Cystoseira neglecta); and (3) substrates neither fish group preferred (i.e. Sargassum palmeri, Plocamium cartilagineum, Gigartina spinosa, Pterocladia sp.). A 3 group discriminant analysis (BMDP7M) 
compared the taxonomic composition (by biomass) of prey assemblages associated with these 3 groups. Other characteristics of prey such as number per $\mathrm{g}$ substrate, average amount of prey biomass per $\mathrm{g}$ substrate, and mean size of prey were also compared among substrate types.

\section{RESULTS}

\section{Birth and growth of young fish}

In 1981, young of the year black surfperch first appeared at our study sites during early May. The first collection of young fish taken in late May was composed entirely of newborns and individuals only a few weeks old (Fig. 1). Young of the year grew very rapidly

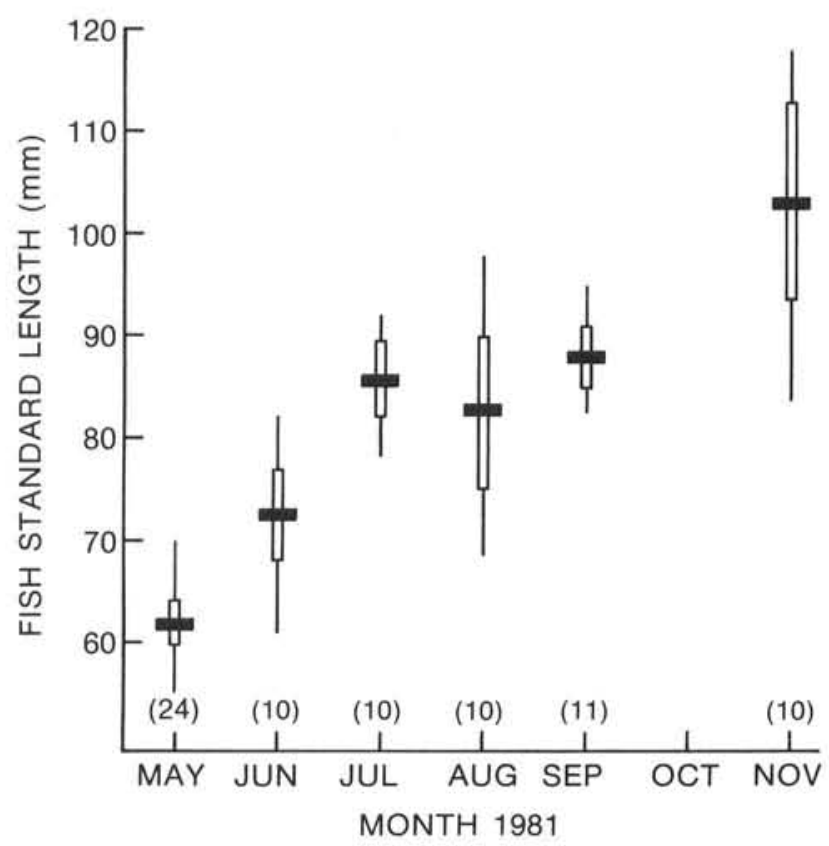

Fig. 1. Embiotoca jacksoni. Standard lengths of young of the year collected at Lionshead, Santa Catalina Island, during 1981. Mean length, $95 \%$ confidence interval, and range in body lengths of individual young captured each month. Young fish were speared as they were encountered by divers on each monthly sampling date

in their first months of life with most individuals nearly doubling their standard length by November (Fig. 1). Fish surviving to 12 mo attained a standard length of about $120 \mathrm{~mm}$. The increase in mean length of samples of juveniles captured throughout the summer was used to approximate the rate of growth of individuals during this time (Fig. 1). This approximation assumed that there was nearly simultaneous release of young among parents, few between-juvenile differences in rate of growth, and little difference in susceptibility of large and small young to predation in later summer and fall months. We have some evidence that release of young was spread over about a 2 -mo period. First, juveniles 55 to $60 \mathrm{~mm}$ SL were occasionally observed as late as Jul, although these individuals were not represented in our random collections of young after Jun. Black surfperch are born at about this size (Isaacson and Isaacson, 1966; Baltz, in press). Second, analysis of daily growth rings on otoliths indicated that smaller individuals captured in Aug-Nov were simply younger than larger juveniles taken then (B. Victor, pers. comm.). This suggested that individual growth rates may not vary substantially despite differences in the month of birth.

\section{Characteristics of the diet of adult and juvenile fish}

Taxonomic composition

The diets of adult and juvenile Embiotoca jacksoni were quite similar in gross taxonomic composition (Table 1). The two fish groups consumed nearly the same range of invertebrate taxa, and both relied heavily on gammarid amphipods. Gammarids comprised about $70 \%$ (both by number and biomass) of the prey in the guts of either fish group. Shrimp, crabs, and isopods were also important components of the diets. Results of a discriminant function analysis that compared the amount of different taxa (by biomass) comprising the diets of individuals (Table 2) indicated that differences between adults and juveniles derived primarily from 4 taxa: sea urchins, gastropods, bivalves, and copepods. Together these 4 prey taxa accounted for only about $5 \%$ of the diets (Table 1 ). Jaeropsid isopods, consumed by adults but not by juveniles in our samples (Table 1), was a poor between-group discriminator because less than half (17 of 44 ) of the adults ate them.

A closer examination of gammarid amphipods consumed by black surfperch revealed several differences between adult and juvenile diets (Table 3 ). Both fish groups took significantly fewer tube-building gammarid individuals than available (equality of percentages test: adults: $\mathrm{t}=9.32,598 \mathrm{df}, \mathrm{p}<0.001$; juveniles: $\mathrm{t}=8.60,598 \mathrm{df}, \mathrm{p}<0.001)$. However, juvenile guts contained significantly more free-living gammarid amphipods than adults (equality of percentages test: $t=2.42,598 \mathrm{df}, \mathrm{p}<0.025$ ). Further, diets of juveniles encompassed only 4 species (or genera) of the gammarid groups available (Table 3 ). This contrasted sharply with adults who took 13 species of gammarid amphipods. Nearly half of the gammarid individuals 
Table 1. Embiotoca jacksoni. Diets of 44 adult and 80 juveniles at Santa Catalina Island. Given are the proportion of prey taxa that comprise fish diets by number and by biomass. Also presented are frequency of prey falling into 9 size classes and proportion of prey biomass in those size categories. Mean number of prey items in juveniles was 291.7 (range 24 to 952); mean number of prey items per adult was 598.6 (range 6 to 1257)

\begin{tabular}{|c|c|c|c|c|}
\hline \multirow{3}{*}{ Prey taxa } & \multicolumn{4}{|c|}{ PREY TAXA } \\
\hline & \multicolumn{2}{|c|}{ Proportion by number } & \multicolumn{2}{|c|}{ Proportion by biomass } \\
\hline & Adults & Juveniles & Adults & Juveniles \\
\hline Gammarid amphipods & 0.768 & 0.693 & 0.681 & 0.770 \\
\hline Sphaeromatid isopods & 0.059 & 0.029 & 0.068 & 0.036 \\
\hline Idoteid isopods & 0.023 & 0.057 & 0.023 & 0.052 \\
\hline Jaeropsid isopods & 0.023 & 0.000 & 0.021 & 0.000 \\
\hline Caridean shrimps & 0.011 & 0.006 & 0.080 & 0.040 \\
\hline Crabs & 0.005 & 0.004 & 0.054 & 0.023 \\
\hline Caprellid amphipods & 0.020 & 0.008 & 0.018 & 0.024 \\
\hline Tanaids & 0.011 & 0.025 & 0.003 & 0.007 \\
\hline Copepods & 0.002 & 0.086 & 0.001 & 0.020 \\
\hline Ostracods & 0.009 & 0.066 & 0.002 & 0.017 \\
\hline Urchins & 0.005 & 0.000 & 0.014 & 0.000 \\
\hline Bivalves & 0.006 & 0.009 & 0.005 & 0.008 \\
\hline \multirow[t]{2}{*}{ Gastropods } & 0.058 & 0.017 & 0.030 & 0.012 \\
\hline & \multicolumn{4}{|c|}{ PREY SIZE DISTRIBUTION } \\
\hline \multirow[t]{2}{*}{ Size class (mg) } & \multicolumn{2}{|c|}{ Proportion by number } & \multicolumn{2}{|c|}{ Proportion by biomass } \\
\hline & Adults & Juveniles & Adults & Juveniles \\
\hline $0.01-0.50$ & 0.309 & 0.638 & 0.087 & 0.378 \\
\hline $0.51-1.00$ & 0.464 & 0.309 & 0.393 & 0.455 \\
\hline $1.01-1.50$ & 0.134 & 0.034 & 0.179 & 0.067 \\
\hline $1.51-2.00$ & 0.041 & 0.006 & 0.072 & 0.020 \\
\hline $2.01-2.50$ & 0.018 & 0.002 & 0.042 & 0.006 \\
\hline $2.51-3.00$ & 0.008 & 0.001 & 0.020 & 0.005 \\
\hline $3.01-3.50$ & 0.006 & 0.000 & 0.020 & 0.000 \\
\hline $3.51-4.00$ & 0.004 & 0.001 & 0.018 & 0.003 \\
\hline$>4.00$ & 0.017 & 0.008 & 0.171 & 0.068 \\
\hline
\end{tabular}

taken by juvenile black surfperch were members of the family Eophliantidae.

Prey size composition and selectivity

Adult and juvenile black surfperch differed substantially in the sizes of prey consumed (Table 1). The mean prey size in juvenile guts $(\overline{\mathrm{X}}=0.45 \mathrm{mg})$ was significantly smaller than that in adult fish $(\overline{\mathrm{X}}=$ $1.02 \mathrm{mg} ; \mathrm{t}=7.03,124 \mathrm{df}, \mathrm{p}<0.001$ ). This pattern, of course, reflected the large difference in mean body lengths of the two fish groups (adults: $\overline{\mathrm{X}}=159.8 \mathrm{~mm}$ $\mathrm{SL}_{\text {; juveniles: }} \overline{\mathrm{X}}=80.6 \mathrm{~mm} \mathrm{SL}$ ). Over $80 \%$ of prey biomass in the diet of juveniles was composed of items weighing less than $1.0 \mathrm{mg}$ (Table 1). These small prey sizes comprised less than $50 \%$ of the prey biomass in adult guts. A discriminant function analysis of prey weight class composition of adult and juvenile diets resulted in a greater than $90 \%$ correct classification of individuals into age group (Table 2). Most of the discrimination resulted from the heavy use of smallest prey by juvenile fish (Table 1).

Manly's (1974) preference values were calculated for each prey weight class to compare availability with use by adult and juvenile fish. The patterns of selectivity are shown in Fig. 2. MANOVA indicated that adults had a significantly different pattern of prey size selectivity from juveniles $(\mathrm{F}=26.68$, $\mathrm{df}=7,48, \mathrm{p}<0.001)$. As shown by Hotelling's $T^{2}$ tests, the preferences displayed by both groups of fish differed significantly from random selection of available prey sizes (Fig. 2: adults: $\mathrm{F}=6.44, \mathrm{df}=9,16, \mathrm{p}<0.001$; juveniles: $\mathrm{F}=$ 169.29 , df $=9,22, p<0.001)$. However, the preference pattern displayed by adults (Fig. 2) was qualitatively very similar to random use of available prey sizes, with a slight overuse of prey in intermediate size classes. Juveniles strongly overused the smallest available prey sizes and rarely captured items in larger size classes. 
Table 2. Embiotoca jacksoni. Classification matrices resulting from discriminant function analyses of taxonomic and size composition of diets of adults $(\mathrm{N}=44)$ and juveniles $(\mathrm{N}=$ 80). Variables used in the analyses are the taxonomic and size class groupings summarized in Table 1

\begin{tabular}{|c|c|c|c|}
\hline \multirow[t]{2}{*}{ PREY TAXA } & \multicolumn{3}{|c|}{$\begin{array}{l}\text { Number of individuals } \\
\text { classified as }\end{array}$} \\
\hline & $\begin{array}{l}\text { Percent correct } \\
\text { classifications }\end{array}$ & $\begin{array}{l}\text { Juve- } \\
\text { niles }\end{array}$ & Adults \\
\hline Juveniles & 95.0 & 76 & 4 \\
\hline Adults & 54.5 & 20 & 24 \\
\hline & \multicolumn{3}{|c|}{$\begin{array}{l}\text { Standardized coefficients } \\
\text { for Canonical Variate I }\end{array}$} \\
\hline \multicolumn{4}{|l|}{ Variable } \\
\hline Urchins & \multicolumn{3}{|c|}{-0.641} \\
\hline Bivalves & \multicolumn{3}{|c|}{0.491} \\
\hline Gastropods & \multicolumn{3}{|c|}{-0.757} \\
\hline Copepods & \multicolumn{3}{|c|}{0.932} \\
\hline \multicolumn{2}{|c|}{ PREY SIZE CLASSES } & \multicolumn{2}{|c|}{$\begin{array}{l}\text { Number of individuals } \\
\text { classified as }\end{array}$} \\
\hline & $\begin{array}{l}\text { Percent correct } \\
\text { classifications }\end{array}$ & $\begin{array}{l}\text { Juve- } \\
\text { niles }\end{array}$ & Adults \\
\hline Juveniles & 91.2 & 73 & 7 \\
\hline \multirow[t]{2}{*}{ Adults } & 90.9 & 4 & 40 \\
\hline & \multicolumn{3}{|c|}{$\begin{array}{l}\text { Standardized coefficients } \\
\text { for Canonical Variate I }\end{array}$} \\
\hline \multicolumn{4}{|l|}{ Variable } \\
\hline $0 \quad-0.50 \mathrm{mg}$ & \multicolumn{3}{|c|}{1.096} \\
\hline $0.51-1.00 \mathrm{mg}$ & \multicolumn{3}{|c|}{0.810} \\
\hline $2.01-2.50 \mathrm{mg}$ & \multicolumn{3}{|c|}{-0.293} \\
\hline $3.01-3.50 \mathrm{mg}$ & \multicolumn{3}{|c|}{-0.331} \\
\hline$>4.01 \mathrm{mg}$ & \multicolumn{3}{|c|}{0.482} \\
\hline
\end{tabular}

\section{Mechanisms leading to ontogenetic dietary patterns}

Fish size and prey size

We first explored the relation between size of a fish and the size of prey captured. Within each age class of fish, a significant positive relation existed (both $\mathrm{p}<0.001$ ) between standard length of a fish and mean weight of a prey. Least squares regressions on these variables yielded similar levels of explained variance for adults $\left(\mathrm{r}^{2}=0.31, \mathrm{~N}=44\right)$ and for juveniles $\left(\mathrm{r}^{2}=\right.$ $0.34, N=80$ ). These data were consistent with the hypothesis that differences in mean prey size between adult and juvenile black surfperch accrued from simple morphological constraints related to body length. However, the very different patterns of prey size selectivity displayed by juveniles and adults (Fig. 2) suggested otherwise. Juveniles strongly preferred the smallest prey sizes and avoided large prey, while adults took even the largest size class of prey in about the proportion of its abundance in our resource samples (Fig. 2). This suggested that juveniles, but perhaps not adults, might be gape-limited. If so, there should be a positive relationship for juveniles between
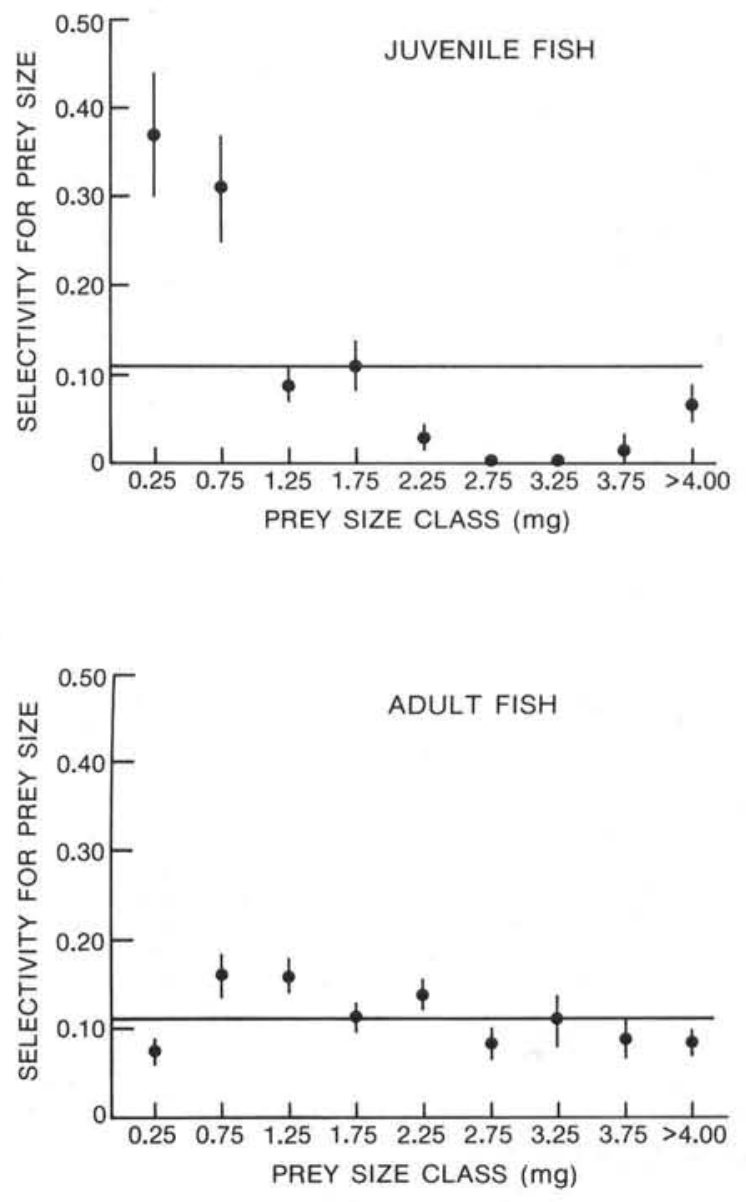

Fig. 2. Embiotoca jacksoni. Pattern of prey size selectivity by juveniles (top) and adults (bottom) at Santa Catalina Island during summer 1981. Selectivity was calculated for each of 9 prey weight classes using Manly's (1974) Preference Index (Chesson 1978, 1983). Horizontal line: random consumption of available prey sizes. Given is the mean \pm 1 standard error for each prey weight class. Adult sample size was 25 (mean standard length of $150 \mathrm{~mm}$ ); juvenile sample size was 31 (mean standard length of $73 \mathrm{~mm}$ )

body size and the largest prey items taken. There was a significant correlation between juvenile standard length and the size of the largest prey item ingested ( $\mathrm{r}=0.67, \mathrm{p}<0.001, \mathrm{~N}=80$ ). By contrast, only $4 \%$ of the variance of the largest prey taken by adults was explained by body size, and the correlation was not significant $(r=0.16, N S, N=44)$. 
Table 3. Taxonomic composition of gammarid amphipods in fish diets and on available foraging substrates. Amphipods are divided into free-living and tube-building species after Barnard (1975). Given are number and proportion (in parentheses) of individual gammarids of each species in diets or in substrate samples

\begin{tabular}{|c|c|c|c|c|c|}
\hline & \multicolumn{2}{|c|}{ IN FISH DIETS } & \multicolumn{3}{|c|}{ ON FORAGING SUBSTRATES } \\
\hline & $\begin{array}{l}\text { Adult } \\
\text { diets }\end{array}$ & $\begin{array}{l}\text { Juvenile } \\
\text { diets }\end{array}$ & $\begin{array}{c}\text { Adult } \\
\text { substrates }\end{array}$ & $\begin{array}{l}\text { Juvenile } \\
\text { substrates }\end{array}$ & $\begin{array}{c}\text { Avoided } \\
\text { substrates }\end{array}$ \\
\hline TUBE BUILDING & .344 & .253 & .684 & .688 & .817 \\
\hline Ampithoe sp. & $39(.130)$ & $76(.253)$ & $54(.180)$ & $50(.167)$ & $51(.170)$ \\
\hline Ericthonius sp. & $23(.077)$ & & $29(.097)$ & $123(.410)$ & $194(.647)$ \\
\hline Gammaropsis sp. & $26(.087)$ & & $116(.387)$ & $26(.087)$ & \\
\hline Ampelisca sp. & $2(.007)$ & & & & \\
\hline Photis sp. & $6(.02)$ & & $4(.013)$ & & \\
\hline Aoroides sp. & $7(.023)$ & & & & \\
\hline Microdeutopus sp. & & & $2(.007)$ & & \\
\hline Chevalia sp. & & & & $7(.023)$ & \\
\hline FREE LIVING & .656 & .747 & .316 & .312 & .183 \\
\hline Hyale sp. & $36(.12)$ & $29(.097)$ & $4(.013)$ & $6(.020)$ & $2(.007)$ \\
\hline Stenothoidae & $1(.003)$ & & & $1(.003)$ & $11(.037)$ \\
\hline Elasmopus sp. & $28(.093)$ & & $52(.173)$ & $15(.050)$ & \\
\hline Pontogeneia-like & $128(.427)$ & $48(.160)$ & $36(.12)$ & $64(.213)$ & $25(.083)$ \\
\hline Podocerus sp. & $1(.003)$ & & & $1(.003)$ & \\
\hline Amphilochus sp. & $1(.003)$ & & & & $5(.017)$ \\
\hline Pleustes sp. & $2(.007)$ & & & & \\
\hline Eophliantidae & & $147(.490)$ & $1(.003)$ & $4(.013)$ & $1(.003)$ \\
\hline Maera sp. & & & $1(.003)$ & & \\
\hline Parapleustes sp. & & & $1(.003)$ & $3(.010)$ & $10(.033)$ \\
\hline Heterophlias sp. & & & & & $1(.003)$ \\
\hline $\begin{array}{l}\text { Number of gammarid } \\
\text { individuals examined }\end{array}$ & $\mathrm{N}=300$ & $\mathrm{~N}=300$ & $\mathrm{~N}=300$ & $\mathrm{~N}=300$ & $\mathrm{~N}=300$ \\
\hline
\end{tabular}

Selection of foraging substrates and availability of prey

Adult and juvenile black surfperch did not show distinct habitat separation at Santa Catalina Island. Rather, the 2 groups of fish foraged together within the same general area. However, adult and juvenile fish displayed persistent differences in the taxa of algae from which prey were harvested (Table 4). These algal substrates were intermingled on a very small spatial scale (on the order of individual plants). Adult Embiotoca jacksoni preferred patches of turf and other planar substrates with low dimensionality (e.g. coralline algae, Zonaria farlowii) and avoided more foliose algae (e.g. Sargassum palmeri) (Table 4). Juveniles tended to ignore some planar substrates (e.g. turf) and certain foliose algae (e.g. Sargassum palmeri) while favoring algal substrates that were structurally similar to unpreferred substrates (e.g. encrusting coralline algae Cystoseira neglecta) (Table 4).

The relations between the size (wet weight) of an alga and the density and sizes of prey it contained were examined using linear regression. Not unexpectedly, larger plants supported greater numbers of invertebrate prey than smaller plants $(r=0.72$, $\mathrm{p}<0.01, \mathrm{~N}=60$ ). But prey were abundant on all substrates. Each alga supported an average of 1092 prey items (considering only those invertebrate taxa consumed by black surfperch). There was no correlation, however, between the size of an alga and the mean size of the invertebrate prey associated with it $(\mathrm{r}=$ $0.01, \mathrm{NS}, \mathrm{N}=60$ ).

We analyzed characteristics of prey on algal types grouped according to fish preferences: algae preferred by adults, those favored mostly by juveniles, and those species neither fish favored (Tables 5 and 6). Analysis of prey density (mean number of prey items per $\mathrm{g}$ wet weight of algae) revealed no significant differences among the 3 categories. The average biomass of gammarid amphipods did, however, differ significantly (Table 5). Substrates not favored by either fish group contained significantly less biomass of gammarids per $g$ of plant than did algae preferred by juveniles or by adults. There was no difference in gammarid biomass available between adult favored and juvenile favored substrates. In addition, avoided algae had significantly (about $30 \%$ ) smaller gammarid amphipods on the average than did algae preferred by either age group (Table 5).

Results of a 3 group discriminant analysis of the 
Table 4. Embiotoca jacksoni. Foraging substrate availability and frequency of bites taken by adults and juveniles at Lionshead during Jul-Aug 1981. Electivity values calculated from Manly's (1974) Preference Index (Chesson, 1983). For substrate availability, standard errors are given in parentheses $(\mathrm{N}=8$ transects); for bites, sample sizes are in parentheses. Substrates are divided into categories based on general growth form

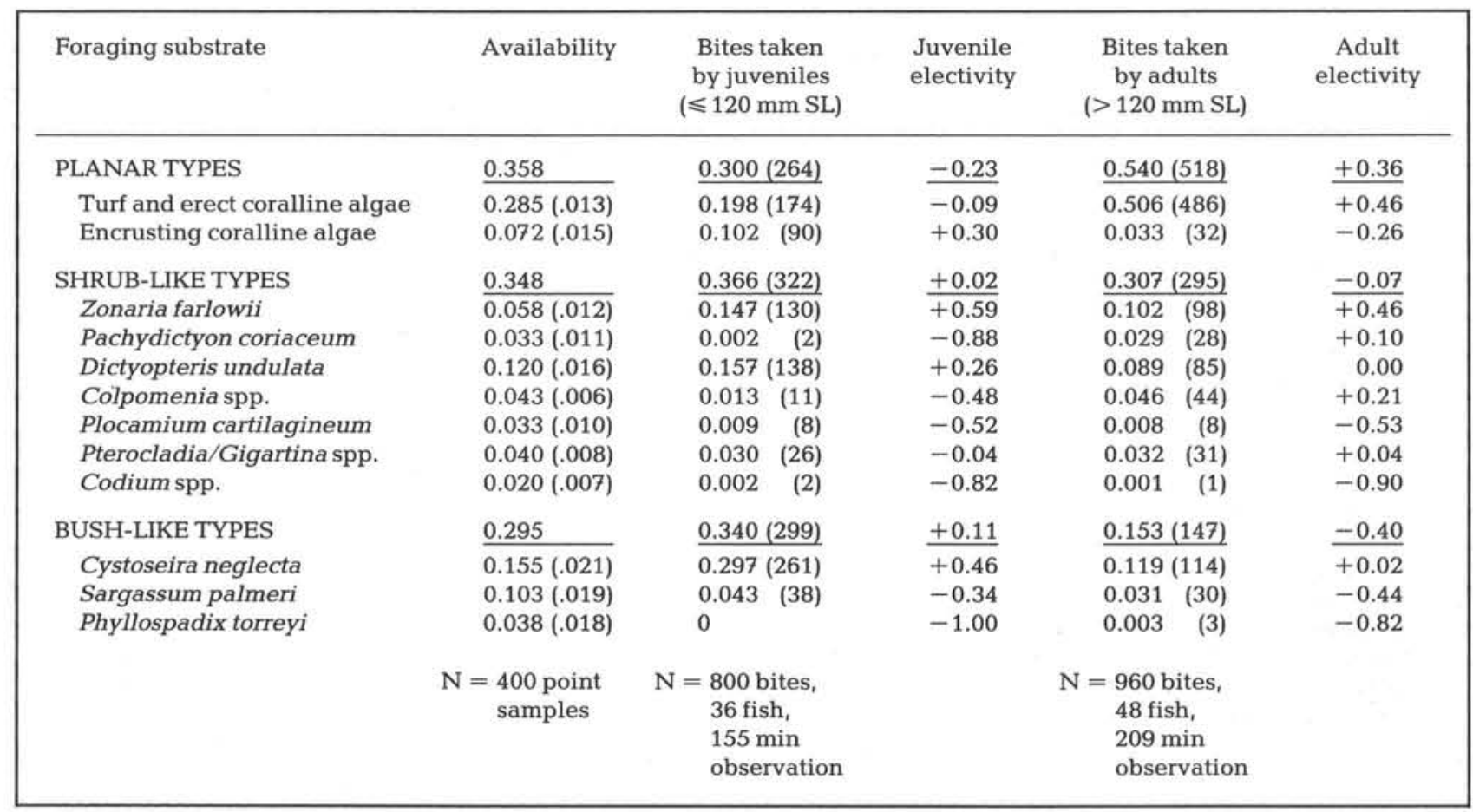

Table 5. Amount of gammarid amphipod biomass and mean size of gammarids available on various types of foraging substrates. Data were log transformed for ANOVA to make variances homogeneous; means presented are back transformed. Means not connected by line differ at $\mathrm{p}<0.05$ by SNK test. Substrate types are (1) algae favored primarily by adults, (2) algae favored by juveniles, (3) algae avoided by both age classes of fish. See Table 6 for plant species composition of groups

\begin{tabular}{|c|c|c|c|c|}
\hline & \multicolumn{2}{|c|}{$\begin{array}{c}\text { Adult } \\
\text { substrate }\end{array}$} & $\begin{array}{l}\text { Juvenile } \\
\text { substrate }\end{array}$ & $\begin{array}{l}\text { Avoided } \\
\text { substrate }\end{array}$ \\
\hline Mg gammarids $\mathrm{g}^{-1}$ algae & \multicolumn{2}{|c|}{6.2} & 7.1 & 4.2 \\
\hline \multirow[t]{2}{*}{$\overline{\mathrm{X}}$ gammarid size $(\mathrm{mg})$} & \multicolumn{2}{|c|}{0.63} & 0.59 & 0.41 \\
\hline & \multicolumn{4}{|c|}{ ANOVA Tables } \\
\hline \multicolumn{5}{|l|}{ Mg gammarids $\mathrm{g}^{-1}$ algae } \\
\hline Source of variation & $\underline{\text { df }}$ & $\underline{\mathrm{MS}}$ & $\underline{\mathrm{F}}$ & \\
\hline Algal types & 2 & 0.275 & $5 \quad 3.600$ & $\mathrm{p}<0.001$ \\
\hline Error & 57 & 0.076 & & \\
\hline \multicolumn{5}{|l|}{$\overline{\mathrm{X}}$ gammarid size } \\
\hline Source of variation & $\underline{\text { df }}$ & $\underline{\mathrm{MS}}$ & $\underline{\mathrm{F}}$ & \\
\hline Algal types & 2 & 0.268 & $8 \quad 5.551$ & $\mathrm{p}<0.001$ \\
\hline Error & 57 & 0.048 & & \\
\hline
\end{tabular}

taxonomic composition of the prey on the 3 categories of foraging substrates indicated that algae avoided by both age classes of fish had significantly more caprellid amphipods (comprising $26 \%$ of total prey biomass) than algae used by either adults or juveniles (caprellids comprised about $5 \%$ of the total prey biomass on these algae). Caprellid amphipods, which are relatively long, thin crustaceans with little usable biomass (Coyer, 1979), were not major components of black surfperch diets (Table 1). In addition, substrates favored by adults contained significantly more idoteids (14 \% of total prey biomass) than algae preferred by juveniles ( $1 \%$ of prey biomass) or avoided by both groups ( $2 \%$ of prey biomass) (Table 6$)$.

\section{Foraging behavior}

Black surfperch used 2 qualitatively distinct modes of feeding to harvest invertebrate prey from benthic substrates. Juveniles usually located prey visually and picked them from the surface of algae. Adults often used winnowing behavior, separating desired prey from unwanted material following relatively indiscriminant bites on a debris-laden substrate such as turf (Table 7). Because handling times differed greatly 
Table 6. Characteristics of invertebrate prey associated with algal substrates used as foraging sites by black surfperch at Santa Catalina Island. Given are the proportion (by weight) that each taxon or weight class comprise on each of 3 substrate types. Standard deviations in parentheses. Substrate types are (1) algae avoided by both age classes of fish, (2) those favored primarily by adults, (3) species preferred most by juvenile fish

\begin{tabular}{|c|c|c|c|}
\hline Taxonomic category & $\begin{array}{l}\text { Avoided }^{1} \text { substrate } \\
\qquad(\mathrm{N}=20)\end{array}$ & $\begin{array}{l}\text { Adult }^{2} \text { substrate } \\
\qquad(\mathrm{N}=20)\end{array}$ & $\begin{array}{c}\text { Juvenile }^{3} \text { substrate } \\
(\mathrm{N}=20)\end{array}$ \\
\hline Gammarid amphipods & $.257(.115)$ & $.429(.181)$ & $.448(.179)$ \\
\hline Sphaeromatid isopods & .109 (.099) & $.014(.042)$ & $.063(.111)$ \\
\hline Idoteid isopods & $.024(.020)$ & $.140(.133)$ & $.010(.008)$ \\
\hline Jaeropsid isopods & $.004(.011)$ & $.010(.019)$ & $.003(.007)$ \\
\hline Caridean shrimps & $.042(.041)$ & $.054(.077)$ & $.033(.041)$ \\
\hline Crabs & $.032(.028)$ & $.018(.027)$ & $.064(.046)$ \\
\hline Caprellid amphipods & $.257(.174)$ & $.070(.140)$ & $.031(.043)$ \\
\hline Tanaids & $.003(.003)$ & $.004 \quad(.002)$ & $.005(.003)$ \\
\hline Copepods & $.009(.008)$ & $.010(.012)$ & $.016(.026)$ \\
\hline Bivalves & $.042(.075)$ & $.054(.074)$ & $.088(.094)$ \\
\hline Gastropods & $.217(.153)$ & $.182(.139)$ & $.224(.140)$ \\
\hline \multicolumn{4}{|l|}{ Weight class } \\
\hline $0 \quad-0.5 \mathrm{mg}$ & $.237(.082)$ & $.200(.074)$ & $.281(.110)$ \\
\hline $0.51-1.0 \mathrm{mg}$ & $.469(.124)$ & $.360(.143)$ & $.296(.099)$ \\
\hline $1.01-1.5 \mathrm{mg}$ & $.091(.034)$ & $.133(.054)$ & $.116(.069)$ \\
\hline $1.51-2.0 \mathrm{mg}$ & $.039(.029)$ & $.069(.045)$ & $.056(.039)$ \\
\hline $2.01-2.5 \mathrm{mg}$ & $.030(.036)$ & $.044(.043)$ & $.039(.037)$ \\
\hline $2.51-3.0 \mathrm{mg}$ & $.017(.023)$ & $.027(.023)$ & $.026(.033)$ \\
\hline $3.01-3.5 \mathrm{mg}$ & $.005(.007)$ & $.015(.018)$ & $.008(.014)$ \\
\hline $3.51-4.0 \mathrm{mg}$ & $.016(.020)$ & $.018(.022)$ & $.015(.027)$ \\
\hline$>4.0 \mathrm{mg}$ & $.097(.082)$ & $.136(.135)$ & $.166(.166)$ \\
\hline \multicolumn{4}{|c|}{$\begin{array}{l}{ }^{1} \text { Includes Sargassum palmeri }(\mathrm{N}=5) \text {, Gigartina spinosa }(\mathrm{N}=5) \text {, Pterocladia sp. }(\mathrm{N}=5) \text {, Plocamium } \mathrm{sp} .(\mathrm{N}=5) \\
{ }^{2} \text { Includes turf }(\mathrm{N}=15) \text { and erect coralline algae }(\mathrm{N}=5) \\
{ }^{3} \text { Includes Zonaria farlowii }(\mathrm{N}=7), \text { Dictyopteris undulata }(\mathrm{N}=6) \text { and Cystoseira neglecta }(\mathrm{N}=7)\end{array}$} \\
\hline
\end{tabular}

between the 2 modes of feeding, and because the 2 age classes of fish used each mode with different frequency, feeding rates differed between adult and juvenile fish. Overall, juveniles averaged 6.3 bites $\min ^{-1}$ while adults averaged a significantly lower feeding rate of 4.2 bites $\min ^{-1}(t=7.71,132 \mathrm{df}$, $\mathrm{p}<0.001)$.

The 2 modes of foraging - picking and winnowing required different amounts of handling but not search time. Adult black surfperch averaged $11.2 \mathrm{~s}$ between bites while picking prey from algae; juveniles averaged $9.9 \mathrm{~s}$ between bites while picking, a rate not significantly different from that of adults $(\mathrm{t}=1.58$, $427 \mathrm{df}, \mathrm{NS}$ ). Most of the interval between picking bites was spent searching the surfaces of plants; handling time was negligible since prey were ingested and swallowed whole within 1 to $2 \mathrm{~s}$ after capture. While using a picking mode, fish began to search for the next prey item immediately after ingestion. By contrast, winnowing behavior required a long handling period because fish stopped while separating prey from debris. The mean handling time associated with winnowing (interval between bite and subsequent cast of debris) was $9.8 \mathrm{~s}$ for adults and $11.4 \mathrm{~s}$ for juveniles; this difference between age classes was not statistically significant ( $\mathrm{t}=1.46,91 \mathrm{df}$, NS). Fish did not actively search for new prey while processing a mouthful of prey-laden debris. The mean time spent by adults in searching for prey following a cast (time between cast and next bite that resulted in a winnow) was $9.0 \mathrm{~s}$, which is not different from the search time associated with picking behavior. Hence, the total interval between bites taken by adults using winnowing behavior (19s) was considerably longer than that associated with picking behavior (10 to $11 \mathrm{~s}$ ). However, winnowing behavior quite probably resulted in numerous prey captures per bite whereas.picking probably yielded one or few prey captures per bite.

\section{Substrate use and mode of foraging}

The best predictor of the foraging behavior used (picking or winnowing) by a black surfperch was the type of substrate from which prey were obtained.

Virtually all bites made by adults from turf involved winnowing behavior. While feeding from turf, adults often took 2 or more bites before ejecting debris. As a 
Table 7. Embiotoca jacksoni. Frequency of bites taken and subsequent winnows by adults and juveniles on foraging substrates at Santa Catalina Island. Differences between adults and juveniles in frequencies of bites/winnow were tested using equality of percentages test (Sokal and Rohlf, 1969)

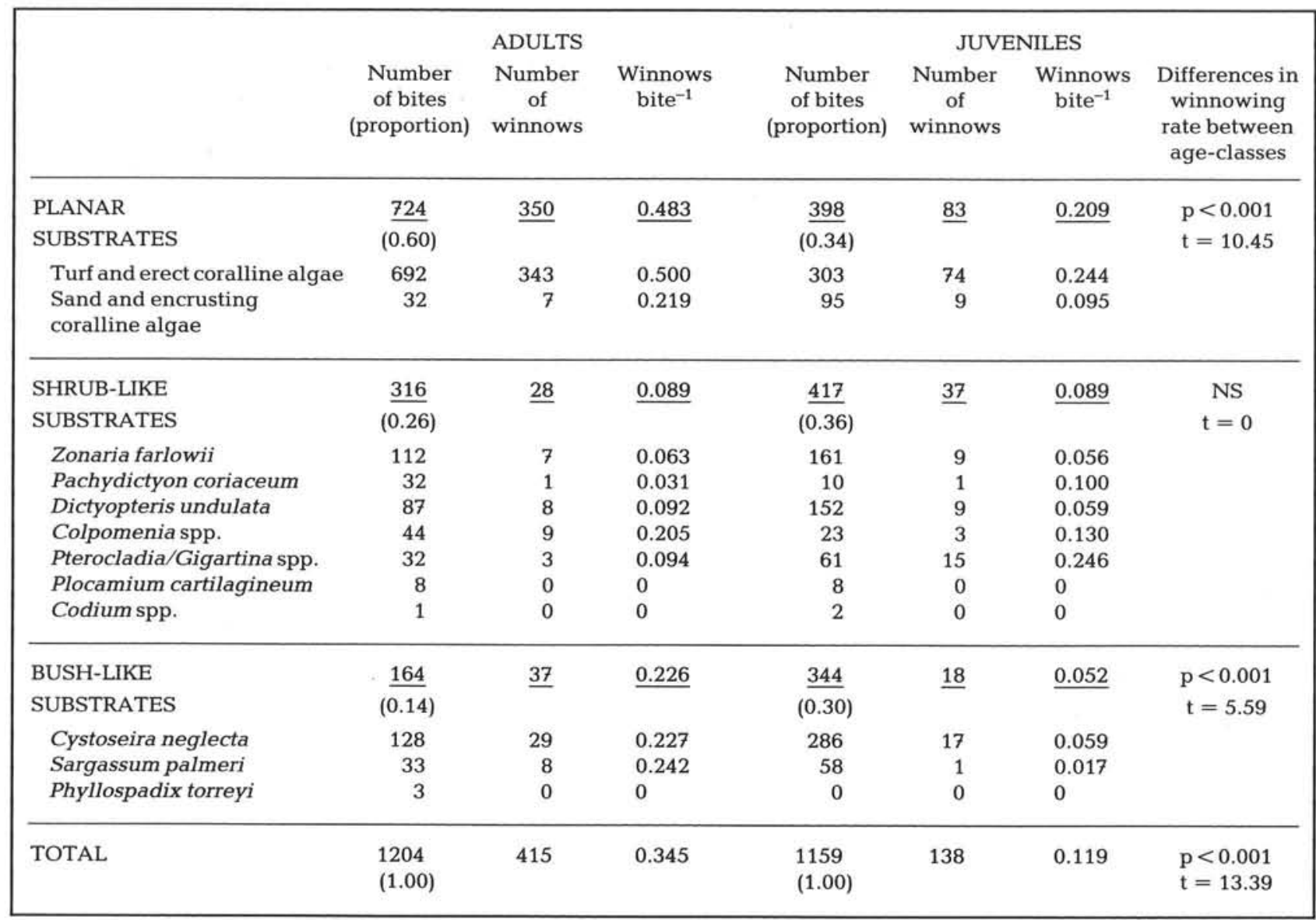

result, adult Embiotoca jacksoni winnowed after $50 \%$ of their bites from turf (Table 7). The propensity of adults to use winnowing behavior appeared to be strongly related to the amount of debris, including amphipod tube mats, associated with a substrate. In general, foliose algae contained substantially less debris and unwanted material than did turf. Picking behavior was the primary mode of feeding by adults on foliose substrates (Table 7). However, adults sometimes employed winnowing behavior while harvesting prey from foliose algae. Winnowing was more common when feeding on bush-like algae than on shrub-like species (Table 7). Of note was the relatively high winnowing rate following bites from Cystoseira neglecta and Sargassum palmeri compared with other foliose algae. These 2 bush-like plants supported exceedingly large amounts of encrusting fauna including bryozoans, sponges, and tunicates; these plants often had large aggregations of tubicolous gammarid amphipods (with tubes) associated with them. For the most part, other foliose species of algae seemed to contain small- er amounts of these materials. While feeding from foliose algae, adults used picking behavior to capture prey on blades and unencrusted portions of stipes. Winnowing occurred most often when bites were taken from holdfasts and encrusted parts of stipes, portions of a plant that contained the most unwanted material.

Based on the proportion of bites taken from various substrate types, together with the modes of foraging associated with each substrate (Table 7), we estimated that adult Embiotoca jacksoni winnowed after about $70 \%$ of their bites. Hence, the bulk of prey items in the gut of adult black surfperch probably were harvested by a posteriori prey selection.

Quite the opposite pattern was displayed by juvenile Embiotoca jacksoni. Most bites made by juveniles involved picking (Table 7). We observed juveniles inspecting surfaces of foliose algae and turf before attempting to capture prey. Most bites were taken from foliose algae (Table 7). Overall, juveniles winnowed after less than $12 \%$ of their bites. As with adults, feeding from turf involved a relatively higher winnow- 
ing frequency compared with foliose algae (Table 7). However, most bites by juveniles on turf still involved picking behavior. As a result, juveniles feeding from turf displayed a significantly lower winnowing frequency than did adults (Table 7). A similar difference between age classes of fish occurred with bush-like substrates; juveniles rarely winnowed following bites from this substrate type. We estimated that overall juveniles employed winnowing behavior in about $20 \%$ of their foraging effort.

We investigated the relation between the size of a fish (standard length) and the frequency of winnowing following a bite (winnows bite ${ }^{-1}$ ) by observing fish of a range of sizes foraging in the field. A strong relation existed between winnowing frequency and length of a fish (Fig. 3). Members of the smallest size class of fish winnowed following just $6 \%$ of their bites. There was

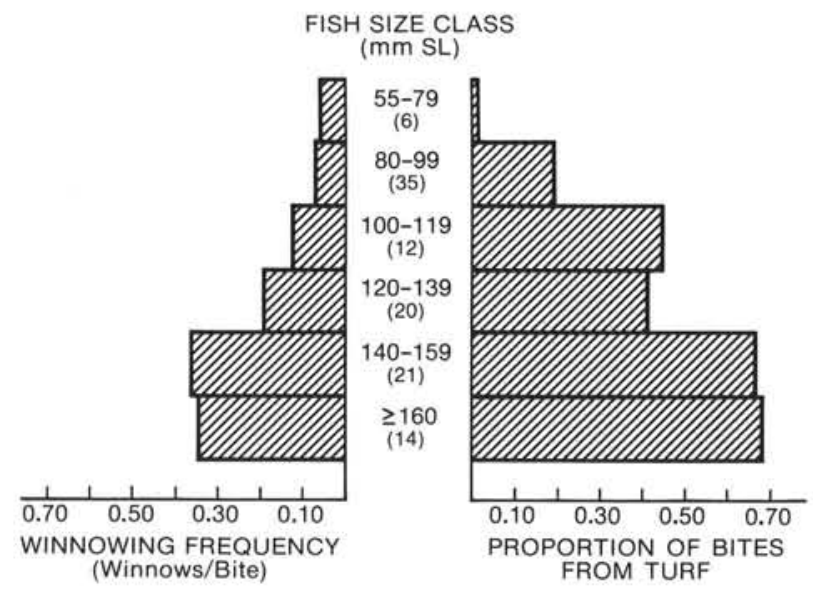

Fig. 3. Embiotoca jacksoni. Winnowing frequency (winnows bite $^{-1}$ ) and relative use of turf as foraging substrate in 6 size classes. Data obtained by observing fish foraging freely in the field; fish lengths estimated. Number of fish in each length class given in parentheses

a sharp rise in winnowing frequency after fish reached a length of $130 \mathrm{~mm} \mathrm{SL}$, a size attained at an age of 15 to $18 \mathrm{mo}$. The largest adults we examined winnowed after more than $35 \%$ of their bites. There was an attendant marked shift by fish to feeding on turf as standard length increased.

\section{DISCUSSION}

There is a growing literature describing age-specific dietary patterns in predators (e.g. Carr and Adams, 1973; Burghardt, 1978; Helfman, 1978; Grossman, 1980; Mushinsky et al., 1982). Two major trends have emerged. First, species displaying ontogenetic shifts in diet tend to have size-structured populations with body size related to age of the individual. Second, the most dramatic dietary shifts often occur relatively early in life. These patterns seem particularly prevalent among fishes (e.g. Carr and Adams, 1973; Keast, 1977b, 1978b; Cadwallader and Eden, 1979; Grossman, 1980; Grossman et al., 1980).

The sorts of differences between diets of juvenile and adult stages of fish include both sizes and taxa of prey consumed (Coyer, 1979; Grossman, 1980). However, prey of different size tend also to be of qualitatively different taxa (Ross, 1977; Werner, 1977; Coyer, 1979; Macpherson, 1979; Grossman, 1980). Hence, an ontogenetic shift to larger prey items can result in taxonomic change, and this can make interpretation of the significance of ontogenetic prey size and taxonomic distributions more difficult. For example, Grossman (1980) found that older bay gobies Lepidogobius lepidus took prey taxa that were larger in size than those taxa consumed by younger gobies.

Although mechanisms have often been forwarded to account for ontogenetic patterns in diet, surprisingly little direct field evidence has been gathered to evaluate the processes involved. Age-related morphological change of fish is certainly important (Lawrence, 1957; Hartman, 1958; Werner, 1974, 1977, 1979; Wankowski, 1979; Zaret, 1980; Hansen and Wahl, 1981). This, together with ontogenetic development of novel foraging tactics, can fundamentally alter the ability of fish to capture some types of prey. Dietary shifts can also result from age-specific patterns of habitat use (spatial or temporal) that lead to differential accessibility of forage items (e.g. Werner and Hall, 1976, 1977, 1979; Bowen and Allanson, 1982). The patterns of habitat selection may stem from differences in susceptibility of juvenile and adult stages to predators (e.g. Grossman et al., 1980; Mittelbach, 1981; Bowen and Allanson, 1982), from intraspecific competition (e.g. Coates, 1980), from age-specific differences in ability to harvest prey among microhabitats (e.g. Holbrook and Schmitt, in press), or other factors. Evaluating the relative importance of such potentially interrelated mechanisms in a given system can be quite complex.

Typically, there is a positive correlation between predator body size and average prey size (Keast, 1965, 1968; Hespenheide, 1971; Kislalioglu and Gibson, 1976a, b; Werner and Hall, 1976; Ross, 1977; Werner, 1977; Coyer, 1979; Macpherson, 1979; Grossman, 1980). Such was the case for both juvenile and adult Embiotoca jacksoni, although less than $35 \%$ of the variance in mean prey size among individuals was explained for either fish group. Presumably mouth gape and/or size of buccal cavity determines the maximum size of an item that can be ingested whole (Lawrence, 1957). Within the size range potentially obtainable, fish may be confronted with constraints on 
efficiency due to size-related differences in capture and handling times (Werner, 1974, 1977). Two lines of evidence suggest that, within the range of prey taxa available to black surfperch, morphology constrains the maximum size of prey captured by juveniles but not adults. Young Embiotoca jacksoni show a very high selectivity for prey in the smallest size classes available (Fig. 2). Between-individual variation in body-size of juveniles explained almost half of the variation among individuals in the size of the largest prey obtained. We interpret these data to mean that juvenile fish are gape-limited (Zaret, 1980). By contrast, adult black surfperch took the largest size of prey in about the same frequency as its availability (Fig. 2). There was no relation between adult body length or mouth size and the size of the largest prey items captured. This suggests that once a black surfperch reaches a standard length of about $130 \mathrm{~mm}$ (corresponding to an age of 15 to $18 \mathrm{mo}$ ), it is capable of consuming the full range of sizes of prey available on algal substrates.

There is a strong link between the pattern of size selectivity of prey (Fig. 2) and the primary mode of foraging used by black surfperch. Young fish principally use picking behavior that results in selection of the smallest sizes available. Older Embiotoca jacksoni most often use a winnowing technique (Table 7) (Schmitt and Coyer, 1982; Laur and Ebeling, 1983) that does not lead to strong size-selection of prey.

Despite the considerable difference in size of prey captured by adults and juveniles, the gross taxonomic compositions of their diets were quite similar (Table 1). We found this result surprising in view of the marked ontogenetic shifts in their foraging behaviors (Table 7; Fig. 3) and use of foraging substrates (Table 4). Several workers have shown dramatic dietary shifts accompanying use of different microhabitats by foraging fish (e.g. Werner and Hall, 1976, 1977; Mittelbach, 1981; Werner et al., 1981; Bowen and Allanson, 1982). This probably does not occur in the surfperch system because prey distributions among different algal substrates are relatively similar (Table 6). One implication of the current study is that older black surfperch eat larger individuals of the same general taxa consumed by younger fish. This is possible since most of the prey taxa in their diets show a rather wide range of body sizes (Schmitt and Coyer, 1982, 1983). To our knowledge, black surfperch represent one of the few examples in which ontogenetic differences in size of prey captured are not accompanied by substantial differences in gross taxonomic composition of diets.

There were, however, important dietary differences between age-classes of black surfperch. The tendency of juveniles to feed on a rather restricted array of gammarid taxa, together with the preponderance of free-living gammarids in the diet, are consistent with the use of a visual foraging strategy. Schmitt and Coyer $(1982,1983)$ found that a congener, the striped surfperch Embiotoca lateralis employed visual picking behavior as adults; the diet of adult $E$. lateralis was characterized by narrow taxonomic breadth and a strong selectivity for free-living gammarid amphipods.

The heavy use of eophliantid gammarid amphipods by juvenile black surfperch seems associated with a picking foraging mode. Eophliantids excavate burrows in the stipes of foliose algae (Barnard, 1969, 1975) but are poorly known because they have rarely been collected. Eophliantids were very uncommon in the invertebrate samples we collected, although they were most abundant ( $1 \%$ of all gammarid individuals) on algal substrates preferred as feeding locations by young fish. It is quite possible that the burrowing mode of life by eophliantids could account for some degree of underrepresentation in our collections. Nevertheless, juvenile black surfperch are quite capable of locating and harvesting this gammarid taxon. During foraging bouts, young fish move along algal stipes and stop frequently to bite. Juveniles probably locate the amphipods or burrows visually, then suck or pick each gammarid from the alga.

Adult Embiotoca jacksoni did not consume eophliantid amphipods and, unlike juveniles, did take a broad range (13 genera) of the gammarid groups available (Table 3). For the most part, the genera of amphipods obtained by older fish had the greatest relative abundances. In addition, adults ate substantially more tubicolous gammarid individuals than did juveniles. These patterns are consistent with those expected based on the principal mode of foraging used by older black surfperch. One primary function of winnowing behavior is to reduce or eliminate debris ingested along with desired prey. Laur and Ebeling (1983) compared winnowed casts with gut contents of adult Embiotoca jacksoni at Naples Reef near Santa Barbara, California. These workers found that casts were comprised of emptied amphipod tubes, plant material, and inorganic debris, as well as undesired invertebrate taxa such as shelled gastropods, bryozoans, and hydroids. These items were rare or absent from the guts of fish they examined. The summation of invertebrates found in casts and in adult diets closely resembled the array available in turf (Laur and Ebeling, 1983). Thus, some degree of taxonomic selection can be achieved by winnowing.

Turf is the foraging substrate that contained the most debris. We suspect that adult Embiotoca jacksoni visually locate prey-rich areas within patches of turf (Holbrook and Schmitt, in press), but use winnowing behavior to harvest prey. They clearly concentrated their foraging effort on turf, which comprised about 
$30 \%$ overall of the benthic cover in our study site (Holbrook and Schmitt, in press). About $60 \%$ of bites made by large E. jacksoni were from this substrate (Table 7). However, older fish were capable of alternating between winnowing prey from turf and picking individual items from the surfaces of foliose algae, often on successive bites. Forage items obtained by picking individuals from algal surfaces might be larger in size and/or more highly prized taxa than those captured by winnowing. It is impossible, unfortunately, to separate the results of each foraging strategy used by an individual fish by comparison of full guts. Although winnowing behavior involved a substantially longer handling time than picking, the difference is possibly compensated for by a larger number of prey captures per bite while winnowing.

Winnowing behavior develops slowly in Embiotoca jacksoni during the first year of life (Fig. 3). This strategy may not be effective or possible until the buccal cavity of a fish attains a certain size and associated structures fully develop. Liem and Greenwood (1981) argued that Embiotoca, despite marked specializations in jaw morphology, are capable of a wide range of feeding actions. Our field observations of adult E. jacksoni confirm that substantially different foraging behaviors are used interchangeably by all individuals during a single foraging bout. Certain species of fish are capable of learning various foraging behaviors (Ringler, 1979) and can show significant behavioral plasticity (Bowen and Allanson, 1982). We do not know the degree to which experience influences ontogenetic development of winnowing behavior in black surfperch. We do know that winnowing is closely associated with feeding from turf (Fig. 3).

We did not directly address one potential mechanism known to influence diets of fish, namely differential susceptibility of individuals to predation. Risk of predation can mold patterns of habitat use, which in turn can result in dramatic differences in diet of young and older fish (e.g. Mittelbach, 1981; Werner et al., 1981; Bowen and Allanson, 1982). Threat of predation on young of the year black surfperch may reinforce the strong selectivity for tall, bush-like algae (Ebeling and Laur, in press). Regardless of the mechanism resulting in patterns of patch preference, we have shown that dissimilar microhabitat use by black surfperch at Santa Catalina Island has only a minor effect on their diets. Ontogenetic differences in the diet of Embiotoca jacksoni arise primarily as a consequence of morphological constraints, which in turn dictate the mode by which prey of various sizes are harvested. Adults are much more flexible than juveniles in the means and, therefore, microhabitats that can be effectively used.

Acknowledgements. We thank J. Bence, S. Cooper, W. Douros, T. Dudley, A. Ebeling, N. Hemphill, M. Hixon, D.
Laur, and C. Osenberg for critical discussions and comments on the manuscript. M. Bercovitch and C. Osenberg assisted with the field work. A. Breyer, P. Chiu, W. Douros, and B. Downes assisted in the laboratory. Financial support was provided by grants from the National Science Foundation (OCE-8110150) and the Academic Senate of the University of California, Santa Barbara. Dr. R. Given and the staff of the Catalina Marine Science Center provided gracious hospitality and logistic support. This is Contribution No. 75 of the Catalina Marine Science Center.

\section{LITERATURE CITED}

Baltz, D. M. (in press). Life history variation among female surfperches (Perciformes: Embiotocidae). Environ. Biol. Fish.

Barnard, J. L. (1969). Gammaridean Amphipoda of the rocky intertidal of California: Monterey Bay to La Jolla. U.S. National Museum Bulletin 258. Smithsonian Institution, Washington, D.C., p. 1-230

Barnard, J. L. (1975). List of Gammaridea. In: Smith, R. I., Carlton, J. T. (ed.) Light's manual. U.C. Press, Berkeley, Calif., p. 357-363

Bowen, S. H., Allanson, B. R. (1982). Behavioral and trophic plasticity of juvenile Tilapia mossambica in utilization of the unstable littoral habitat. Environ. Biol. Fish. 7: $357-362$

Burghardt, G. M. (1978). Behavioral ontogeny in reptiles: whence, wither, and why? In: Burghardt, G. M., Berkoff, M. (ed.) The development of behavior: comparative and evolutionary aspects. Garland STPM Press, New York, p. 149-173

Cadwallader, P. L. (1975). The food of the New Zealand common river galaxias, Galaxias vulgaris Stokell (Pisces: Salmoniformes). Aust. J. mar. Freshwat. Res. 26: 15-30

Cadwallader, P. L., Eden, A. K. (1979). Observations on the food of the Macquarie Perch, Macquaria australasica (Pisces: Percichthyidae), in Victoria. Aust. J. mar. Freshwat. Res. 30: 401-409

Carr, W. E. S., Adams, C. A. (1973). Food habits of juvenile marine fishes occupying seagrass beds in the estuarine zone near Crystal River, Florida. Trans. Am. Fish. Soc. 102: $511-540$

Chesson, J. (1978). Measuring preference in selective predation. Ecology 59: 211-215

Chesson, J. (1981). The role of alternative prey in the control of mosquitoes by notonectids. Ph. D. dissertation, U.C. Santa Barbara

Chesson, J. (1983). The estimation and analysis of preference and its relationship to foraging models. Ecology 64: 1297-1304

Coates, D. (1980). Prey-size intake in Humbug damselfish, Dascyllus aruanus (Pisces: Pomacentridae) living within social groups. J. Anim. Ecol. 49: 335-340

Coyer, J. A. (1979). The invertebrate assemblage associated with Macrocystis pyrifera and its utilization as a food source by Kelp forest fishes. Ph. D. dissertation, University of Southern California

DeMartini, E. E. (1969). A correlative study of the ecology and comparative feeding mechanism morphology of the Embiotocidae (surf-fishes) as evidence of the family's adaptive radiation into available ecological niches. Wasmann J. Biol., Univ. San Francisco 27: 177-247

Ebeling, A. W., Bray, R. N. (1976). Day versus night activity of reef fishes in a kelp forest off Santa Barbara, California. Fish. Bull. U.S. 74: 703-717 
Ebeling, A. W., Laur, D. R. (in press). The influence of plant cover on surfperch abundance at an offshore temperate reef. Environ. Biol. Fish.

Ebeling, A. W., Larson, R. J., Alevizon, W. S. (1980a). Habitat groups and island-mainland distribution of Kelp-bed fishes off Santa Barbara, California. In: Power, D. M. (ed.) Multidisciplinary symposium on the California Islands. Santa Barbara Mus. Nat. Hist., Santa Barbara, p, 403-431

Ebeling, A. W., Larson, R. J., Alevizon, W. S., Bray, R. N. (1980b). Annual variability of reef-fish assemblages in Kelp forests off Santa Barbara, California. Fish. Bull. U.S. 78: 361-377

Ellison, J. P., Terry, C., Stephens, J. S. Jr. (1979). Food resource utilization among five species of Embiotocids at King Harbor, California, with preliminary estimates of caloric intake. Mar. Biol. 52: 161-169

Flemer, D. A., Woolcott, W. S. (1966). Food habits and distribution of the fishes of Tuckahoe Creek, Virginia, with special emphasis on the bluegill, Lepomis m. macrochirus Rafinesque. Chesapeake Sci. 7: 75-89

George, E. L., Hadley, W. F. (1979). Food and habitat partitioning between Rock Bass (Ambloplites rupestris) and Smallmouth Bass (Micropterus dolomieui) young of the year. Trans. Am. Fish. Soc. 108: 253-261

Grossman, G. D. (1980). Ecological aspects of ontogenetic shifts in prey size utilization in the Bay Goby (Pisces: Gobiidae). Oecologia 47: 233-238

Grossman, G. D., Coffin, R., Moyle, P. B. (1980). Feeding ecology of the Bay Goby (Pisces: Gobiidae). Effects of behavioral, ontogenetic, and temporal variation on diet. J. exp. mar. Biol. Ecol. 44: 47-59

Hansen, M. J., Wahl, D. H. (1981). Selection of small Daphnia pulex by yellow perch fry in Oneida Lake, New York. Trans. Am. Fish. Soc. 110: 64-71

Hartman, G. F. (1958). Mouth size and food size in young rainbow trout, Salmo gairdneri. Copeia 1958: 233-234

Heins, D. C., Clemmer, G. H. (1975). Ecology, foods and feeding of the Longnose shiner, Notropis longirostris (Hay), in Mississippi. Am. Midl. Nat. 94: 284-295

Helfman, G. S. (1978). Patterns of community structure in fishes: summary and overview. Environ. Biol. Fish. 3: 129-148

Hespenheide, H. A. (1971). Food preference and the extent of overlap in some insectivorous birds, with special reference to the Tyrannidae. Tbis 113: 59-72

Hespenheide, H. A. (1973). Ecological inferences from morphological data. Ann. Rev. Ecol. Syst. 4: 213-229

Hespenheide, H. A. (1975). Prey characteristics and predator niche width. In: Cody, M. L., Diamond, J. M. (ed.) Ecology and evolution of communities. Belknap Press, Cambridge, Mass., p. $158-180$

Hixon, M. A. (1980a). Competitive interactions between California reef fishes of the genus Embiotoca. Ecology 61: 918-931

Hixon, M. A. (1980b). Food production and competitor density as the determinants of feeding territory size. Am. Nat. 115: $510-530$

Hixon, M. A. (1981). An experimental analysis of territoriality in the California reef fish Embiotoca jacksoni (Embiotocidae). Copeia 1981: 653-665

Holbrook, S. J., Schmitt, R. J. (in press). Experimental analyses of patch selection by foraging black surfperch (Embiotoca jacksoni). J. exp. mar. Biol. Ecol.

Isaacson, P. A., Isaacson, D. M. (1966). Notes on the life history of the black perch, Embiotoca jacksoni, Agassiz. Trans. Am. Fish. Soc. 95: 107-109

Keast, A. (1965). Resource division amongst cohabiting fish species in a bay, Lake Opinicon, Ontario. In: Proceedings of the 8th Conference of Great Lakes Research, University of Michigan, p. 106-132

Keast, A. (1968). Feeding of some Great Lake fishes at low temperatures. J. Fish. Res. Bd Can. 25: 1199-1218

Keast, A. (1977a). Mechanisms expanding niche width and minimizing intraspecific competition in the rock bass and bluegill sunfish (Centrarchidae). Evolutionary Biology 10: 333-395

Keast, A. (1977b). Feeding and food overlaps between the year classes relative to the resource base, in the yellow perch, Perca flavescens. Environ. Biol. Fish. 2: 55-70

Keast, A. (1978a). Trophic and spatial interrelationships in the fish species of an Ontario temperate lake. Environ. Biol. Fish. 3: 7-31

Keast, A. (1978b). Feeding interrelations between age-groups of pumpkinseed (Lepomis gibbosus) and comparisons with bluegill (L. macrochirus). J. Fish Res. Bd Can. 35: 12-27

Kislalioglu, M., Gibson, R. N. (1976a). Prey 'handling time' and its importance in food selection by the 15-spined stickleback, Spinachia spinachia (L.). J. exp. mar. Biol. Ecol. 25: 151-158

Kislalioglu, M., Gibson, R. N. (1976b). Some factors governing prey selection by the 15-spined stickleback, Spinachia spinachia (L.). J. exp. mar. Biol. Ecol. 25: 159-169

Laur, D. R., Ebeling, A. W. (1983). Predator-prey relationships in a guild of surfperches. Environ. Biol. Fish. 8: 217-229

Lawrence, J. M. (1957). Estimated sizes of various forage fishes largemouth bass can swallow. In: Proceedings of the S.E. Association of Game and Fisheries Commission 11: $220-226$

Lemly, A. D., Dimmick, J. F. (1982). Growth of young-of-theyear and yearling Centrarchids in relation to zooplankton in the littoral zone of lakes. Copeia 1982: 305-321

Leum, L. L., Choat, J. H. (1980). Density and distribution patterns of the temperate marine fish Cheilodactylus spectabilis (Cheilodactylidae) in a reef environment. Mar. Biol. 57: 327-337

Liem, K. F., Greenwood, P. H. (1981). A functional approach to the phylogeny of the Pharyngognath Teleosts. Am. Zool. 21: 83-101

Macpherson, E. (1979). Ecological overlap between macrourids in the western Mediterranean Sea. Mar. Biol. 53: 149-159

Manly, B. F. J. (1974). A model for certain types of selection experiments. Biometrics 30: 281-294

Mittelbach, G. C. (1981). Foraging efficiency and body size: a study of optimal diet and habitat use by bluegills. Ecology 62: $1370-1386$

Mushinsky, H. R., Hebrard, J. J., Vodopich, D. S. (1982). Ontogeny of water snake foraging ecology. Ecology 63: 1624-1629

Ringler, N. H. (1979). Prey selection by benthic feeders. In: Clepper, H. (ed.) Predator-prey systems in fisheries management. Sport Fishing Institute, Washington, D.C., p. 219-229

Ross, S. T. (1977). Patterns of resource partitioning in searobins (Pisces: Triglidae). Copeia 1977: 561-571

Schmitt, R. J., Coyer, J. A. (1982). The foraging ecology of sympatric marine fish in the genus Embiotoca (Embiotocidae): importance of foraging behavior in prey size selection. Oecologia 55: 369-378

Schmitt, R. J., Coyer, J. A. (1983). Variation in surfperch diets between allopatry and sympatry: circumstantial evidence for competition. Oecologia 58: 402-410 
Schoener, T. W. (1968). The Anolis lizards of Bimini: resource partitioning in a complex fauna. Ecology 49: 704-726

Sokal, R. R., Rohlf, F. J. (1969). Biometry. W. H. Freeman and Co., San Francisco

Tarp, F. H. (1952). A revision of the family Embiotocidae. Calif. Fish Game, Fish. Bull. 88

Wankowski, J. W. J. (1979). Morphological limitations, prey size selectivity, and growth response of juvenile Atlantic salmon, Salmo salar. J. Fish. Biol. 14: 89-100

Werner, E. E. (1974). The fish size, prey size, handling time relation in several sunfishes and some implications. J. Fish. Res. Bd Can. 31: 1531-1536

Werner, E. E. (1977). Species packing and niche complementarity in three sunfishes. Am. Nat. 111: 553-578

Werner, E. E. (1979). Niche partitioning by food size in fish communities. In: Clepper, H. (ed.) Predator-prey systems in fisheries management. Sport Fishing Institute, Washington, D.C., p. 311-322

Werner, E. E., Hall, D. J. (1976). Niche shifts in sunfishes: experimental evidence and significance. Science, N.Y. 191: 404-406

Werner, E. E., Hall, D. J. (1977). Competition and habitat shift in two sunfishes (Centrarchidae). Ecology 58: 869-876

Werner, E. E., Hall, D. J. (1979). Foraging efficiency and habitat switching in competing sunfishes. Ecology 60: 256-264

Werner, E. E., Mittelbach, G. G., Hall, D. J. (1981). The role of foraging profitability and experience in habitat use by the bluegill sunfish. Ecology 62: 116-125

Zaret, T. M. (1980). Predation and freshwater communities. New Haven, Yale University Press, Conn.

This paper was presented by Professor J. S. Pearse; it was accepted for printing on April 22, 1984 